
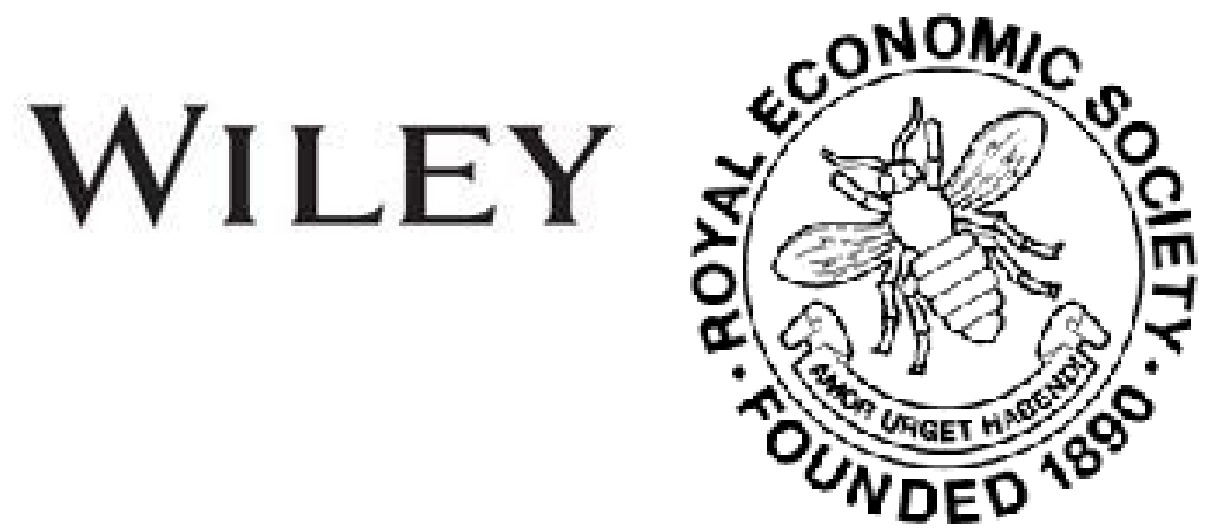

\title{
Gaps in Our Factory Legislation
}

Author(s): B. L. Hutchins

Source: The Economic Journal, Vol. 18, No. 70 (Jun., 1908), pp. 221-230

Published by: Wiley on behalf of the Royal Economic Society

Stable URL: http://www.jstor.org/stable/2220701

Accessed: 27-06-2016 02:36 UTC

Your use of the JSTOR archive indicates your acceptance of the Terms \& Conditions of Use, available at

http://about.jstor.org/terms

JSTOR is a not-for-profit service that helps scholars, researchers, and students discover, use, and build upon a wide range of content in a trusted digital archive. We use information technology and tools to increase productivity and facilitate new forms of scholarship. For more information about JSTOR, please contact support@jstor.org.

Wiley, Royal Economic Society are collaborating with JSTOR to digitize, preserve and extend access to The Economic Journal 


\section{GAPS IN OUR FACTORY LEGISLATION.}

THE following suggested amendments and additions to the Factory Act do not, of course, represent the whole difference between the actual and the ideal, between that which is and that which ought to be. If an enlightened Government in a new country, with industries as yet undeveloped, were to have a free hand in determining the conditions under which employment should be carried on, unhampered by custom, prejudice, or poverty, it çould construct, and hope to enforce, a much more advanced and generous scheme, and be it observed, there is little doubt that such legislation would be, not only advantageous to the health of the people, but a powerful aid towards industrial efficiency. There is a great mass of evidence which tends to show that labour carried on for comparatively short hours, under the best sanitary conditions, and for high wages, eliminating the competition of child labour, is very much more productive than is the work of sweated industries, where the opposite conditions prevail. Further, it is evident that a country in which such a high standard of conditions could be maintained would enjoy an enormous advantage over its commercial competitors from the diminution of poverty, disease, and pauperism, which would be its reward.

Our position in England is very different. Factory legislation had its small beginnings in the early nineteenth century, at a time when industry was already more or less demoralised by unregulated, one might say anarchic, competition, when child labour was recognised by custom and even approved by philanthropy, and capital had established a sort of prescriptive right to the utmost exploitation of labour. No statesman at that time could dare to dream of a large constructive scheme of social reformthe very poverty of the people would have made such an idea impossible. All that was attempted was to set limits to competition in its worst excesses, to prevent the night work of 
children, for instance, and to restrict their hours of labour. Even these measures, tardy and inadequate as they seem to us, had a great deal of prejudiced opposition to meet. The roots of custom and habit are hard to disentangle in an old country like ours, and the reformer has perforce to content himself with progress step by step, ever dogged and hindered by the knowledge that the greatest obstacle to progress is that very poverty of the people that he is working to diminish. We may be perfectly convinced of the soundness of the economic argument that long hours and insanitary conditions diminish efficiency, and, therefore, in the long run, tend to keep wages low, but we cannot entirely put aside the reflection that a higher standard of requirements will perchance lessen the earnings of the already underpaid, or even throw them out of work, at the moment. Factory legislation has never aimed at more than the redress of the abuse most clearly perceived at a given moment. It has in this way, however, progressed from small beginnings until at the present day it forms, not, indeed, the comprehensive scheme of race preservation indicated above, but at all events a very substantial measure of protection against the manifold dangers incidental to industry, dangers from which " the labourer," to use the vague generalisation of the classical economists, is usually either by age, sex, ignorance, or economic dependence, not capable of guarding himself or herself. Our social reform is a process of becoming rather than of being. The individualist asks despairingly, "Where are we to stop?" The answer must be, "Certainly not yet." Opportunist methods and piecemeal reform are the English tradition. Consequently the work, like women's work, "is never done." The subject of the present article is merely to point out the next steps. We may separate the subjectmatter as follows : (1) Duration of work ; (2) Health and safety ; (3) Payment of wages.

(1) As regards the hours of work, there is a growing feeling that these are too long, especially for growing girls. The period of employment under $1 \mathrm{Edw}$. VII. c. 22 is for women and young persons (i.e., boys and girls from 14 to 18) 12 hours, with intervals for meals which must be not less, than $\mathbf{1}_{2} \frac{1}{2}$ hours in non-textile factories and workshops, and 2 hours in textile factories. This means that any girl of 14 , or of 13 , who has passed the educational requirements in force, may work " round the clock," i.e., from 6 to 6,7 to 7 , or 8 to 8 . When I have put the matter thus in addressing meetings of ladies not familiar with the subject, I have sometimes been met with an incredulous look, and the 
objection, "I thought the Factory Act had altered all that." It certainly is somewhat remarkable that a century of legislation has done no more for these young growing girls, who, at a peculiarly critical and important age, may still be employed for hours longer than most men consider a proper working day for themselves. Shorter hours for all protected workers would seem to be an appropriate measure of relief. It may be remarked that in non-textile factories it has for some time been customary not to work the full legal hours. About nine hours is the rule, for instance, in the Birmingham brass works; an employer in this trade once very kindly explained to me in detail how it was that he found it actually bad economy to keep going more than nine hours, because the girls could not keep their attention fixed longer, made more "scrap" and wasted material. This seems to be commonly recognised in metal work, pottery, \&c., but for some obscure reason textile factories customarily work the full legal hours-10 per day. Now it is important to remember that these hours mean more work and more fatigue than they did when the normal day was first introduced 50 odd years ago. The speeding up of machinery has increased the strain, and even as long ago as 1872 shorter hours were agitated for by the trade unions. In the following year Dr. Bridges and Mr. Holmes were instructed by the Local Government Board to hold an inquiry as to the health of women and young workers in textiles. They reported, after taking a considerable quantity of evidence, that since the passing of the Act of 1847, the strain on the workpeople had certainly increased, i.e., each operative had a larger amount of machinery to attend to ; the machinery was driven at greater speed; the practice of giving overlookers and foremen a premium on the work done impelled them to exact steadier and harder work than formerly. The Act of 1874 , however, merely required an additional half-hour for rest and meals daily. In the intervening period the strain has undoubtedly increased. One of H.M.'s inspectors tells me that "both in cotton and woollen the strain of the full hours with speeding up is almost intolerable to the less robust women and girls." Miss Anderson, Chief Lady Inspector, stated before the Physical Deterioration Committee that in her opinion the legal hours were too long- " longer for women than men would stand in their own organised industries" (Evidence, q. 1,498). Her Memorandum, included with the Committee's Report, should also be studied in this connection. Dr. Oliver, in considering the subject of "speeding up," writes : "That there is greater strain upon the nervous system, more 
exhaustion, and consequently need for greater leisure, few will deny, and that in many instances the hard work induces premature old age goes without saying. Will this speeding up tend to make female mill-workers better mothers and help them to give birth to healthy and robust children, or to infants who are puny, ill-nourished, and of a highly-strung, nervous system? . . . There is a limit beyond which the speeding of machinery cannot be run without detriment to the health of the operators, unless their hours of work are materially shortened." 1 The extreme monotony of factory work is in itself a cause of strain. This was noted by Dr. Bridges and Mr. Holmes in the report already quoted (p. 43), and has more recently been observed by Miss Vines (see Factory Inspectors' Report for 1904, p. 260).

But although the textile factories customarily work up to the full limit of the legal hours, it has to be noted that they are by law better regulated than the non-textile factories. In the former, work may not be continued by a child, young person, or woman for more than $4 \frac{1}{2}$ hours without a break. In the latter the spell may be, and frequently is, 5 hours. Taking into consideration the hurry and pressure under which modern industry is carried on, this is too long a spell. Another grievance is that the pause for a midday meal is frequently too short. An hour's interval must be allowed before 3 o'clock p.m., but this hour may be divided, half an hour taken perhaps before beginning work (8.30 instead of 8 ), and only half an hour need then be allowed for dinner. The results of so inadequate an interval after a long morning's work are considered by Miss Anderson to be very serious. This restriction of the dinner-hour appears to be a common custom in the London dress trades, and accounts for much indigestion, anæmia, and sickly looks noticeable among the young women working in these trades.

Another highly desirable reform in regard to hours of work would be the abolition of overtime. This has been consistently advocated by the trade unions, especially by the Women's Trade Union League, for many years. Overtime has been made illegal for young persons in all trades, and also for women in textile, and in some non-textile, industries. Exemptions are still permitted in industries in which the nature of the employment is supposed to require elasticity, as, for instance, the making of wearing apparel, Christmas presents, \&c., \&c. The workers in these employments are thus liable to be kept for very long spells of work at certain seasons. Considering how long the daily hours under the

\footnotetext{
1 Oliver, Diseases of Occupations, p. 3.
} 
Factory Act still are, it appears utterly unreasonable to require overtime as well. A master once said to me, "In nine hours the girls have done as much work as it is in them to do." The permission of overtime is simply a premium on irregularity and bad organisation. Permission to make up "lost time" and work overtime used to be granted in the textile industry, but it has gradually been recognised as a source of weakness, the exceptions have been shut off one by one, and the " normal day" has become more and more the standard. The trend is unmistakably towards the prohibition of overtime, and the sooner the better, if we value the health of working girls and women.

It is necessary to remark here that even if the working day is reduced by one hour, and overtime prohibited, the state of things is still not satisfactory in regard to young workers. A full day's work, whether 10 hours or 9 , ought not to be required of a boy, still less of a girl, of 13 or 14 . The question is a difficult one, because, as most people now know, the organisation of a textile factory (possibly of other factories) involves a subdivision of labour, which renders the elder and more skilled workers dependent on the co-operation of the younger and less skilled. The spinner cannot work without his " piecer." This difficulty might perhaps be got over by raising the age of half-timers to 16 . If this operated as a discouragement on the employment of young workers, it might, on the other hand, tend to increase the demand for the labour of adult women, and raise their wages. One of H.M.'s inspectors tells me that the present tendency is to employ girls rather than women, which has the effect of depressing piece rates. From the social point of view, adult workers should be preferred. May not some of the high infant mortality of the cotton towns be due to the overstrain of women in their early life, before maturity?

(2) In regard to improving the regulations for health much might be said, did space permit. It is a singular fact that with all our national pride in cleanliness, the Factory Act includes no provision in regard to washing appliances, save for certain specified dangerous trades. In France this provision is required in factories and workshops generally; English law apparently regards wash-basins, soap, and towels as an expense only to be justified when deadly peril, such as lead or phosphorus poisoning is involved. In a recent report, Miss Anderson says that the need for washing appliances is increasingly felt among women and girls (surely a hopeful sign), and has a moral and social, as well as a hygienic, value. The girl who is contented to go home dirty and 
unkempt from the long day's work is not the most self-respecting of workers. Even in cases where the work is specially hot and dirty (is not most work more or less hot and dirty?), the lady inspectors have no power to do more than advise this provision, which one would expect the ordinary self-respect of employers to dictate. Miss Anderson says that employers will complain to her of the roughness or carelessness of the young women they employ, yet do not realise how extraordinarily " rough, primitive, and uncivilised" are the surroundings in which too often they place their employees, or how closely these phenomena are related. It is pleasanter to read that the same observer has often noted with surprise and admiration the efforts working women will make, in the face of the greatest difficulties, to turn homewards with a neat and cleanly appearance. The Chief Inspector has said that washing accommodation has a civilising influence, and he has rarely known such provision to be unused or despised. Probably no class in any society takes such an open and almost childish pride in the habits that promote physical health and refinement as the English wealthy classes. Might they not occasionally ask themselves what are the conditions in the houses from which they draw their rents, the factories from which they draw their profits, or the industries in which they invest their capital? Much is done by the best employers, and the law might surely try to awaken the sleeping conscience of the worse.

Another important point in regard to health is the medical inspection of young persons to ascertain their physical fitness for work or for special kinds of work. This is already done for children on entering the factory, and the inspectors have power to require the certifying surgeon to make a re-inspection of young persons under 16. It was represented to the Physical Deterioration Committee that this re-examination might properly be made general and compulsory, and extended to all young workers under 18 or even 21. Dr. Scott pointed out that some boys, who might be fully capable of useful work, were yet too slow-witted to deal safely with machinery, and might be the cause or the victim of horrible accidents. The same gentleman strongly urged the medical inspection of boys before working in coal mines, and the abolition of half-time for children. He considered that boys who came straight from school to work at 14 made better and more capable and regular workers. Another observer, who has recently visited a good many factories on business, has told me he was greatly struck by the fact that the employment of children seems to be dying out in the best conducted factories, and to linger on in 
those which are most crowded, worst ventilated, and altogether precisely the most undesirable for children to be in.

Among other provisions for health which are still not required by law, but are urgently needed, their absence forming the subject of many complaints to the women inspectors, are the provision of mess-rooms; these are chiefly needed in large works, and might be dispensed with in small workshops or where there are facilities for meals accessible in the immediate neighbourhood. It is important that mess-rooms should be under the supervision of the inspector, instead of, as now, outside it. Cloakrooms or provision suitable for outdoor garments are also highly necessary, many workers having a long walk and arriving wet through in bad weather. The provision of adequate light in workrooms is a singular omission from the law. One of the lady inspectors writes to me that some provision is necessary to ensure that both by day or artificial light all workers should have sufficient and properly placed light on their work. An inadequate or badlyplaced arrangement causes straining of eyesight, stooping or twisting of shoulders, headache, not to mention more terrible dangers from machinery worked in shadow or in an uncertain fitful light. The lighting of staircases, passages, yards, and sanitary conveniences is also necessary both for physical and moral reasons.

In regard to one of the most important of the Factory Act provisions for health-namely, the prohibition of work after confinement-it is not possible here to say much, as the adequate discussion of it would take us outside the subject of the Factory Act. Every competent person is agreed that the prohibition of work for one month is altogether insufficient, but everyone also knows that the poverty of the women themselves is the most frequent cause of breaches of the law, and in default of some system of national insurance or compensation for the expenses of maternity, it is difficult to see how the period of unemployment can be extended. One useful amendment, however, could be made in the existing law, and that is the deletion of the word "knowingly." At present the employer can escape a fine if he can show that he did not know, or could not be expected to know, that the woman had given birth to a child within four weeks. It has actually been decided in a court of law that an employer which is a company cannot have cognisance of such a fact, and, therefore, is not liable to a fine for employing the woman in such circumstances (see Report for 1904, p. 273). It is extremely difficult for the inspectors to get a 
conviction under this section, even when the offence is practically certain. Other useful provisions would be to require that the occupation of mothers be returned in the registration of the deaths of infants, and to require mothers to produce a medical certificate on returning to work. But the main question is an economic one, which cannot be dealt with under the Factory Act alone.

The carrying of heavy weights by women and young persons is frequently mentioned by H.M.'s inspectors as being highly dangerous to health. Of all uses to put a woman to, surely that of beast of burden is one of the most repugnant and inhuman. Some provision could surely be made to check the practice, which in the case of children has been forbidden by the Act of 1903 . The enforcement of similar regulations in the case of women and girls would result either in the increased employment of men or in the more extended use of labour-saving appliances, as trolleys, \&c., either of which would be far better social economy than the overstrain of these poor women, often bearing the triple burden of mother, wife, and industrial worker.

Miss Anderson has stated that in her opinion it is possible to conduct factory labour in such a manner as to involve no harm to health whatever. The conditions that injure health, as, for instance, the quantity of dust generated in certain processes, are not essential to any employment, but admit of a remedy if due scientific means are used. It is interesting to recall that about 90 years ago Sir Richard Arkwright described to Peel's Committee the means he used to prevent dust in the process of cleaning cotton, and said there need be no dust. Miss Anderson told the Physical Deterioration Committee that among the causes adverse to health in industry were dusty processes, extremes of temperature, and working in a damp atmosphere. There has been a great improvement in the application of exhaust ventilation to the removal of injurious dust and in remedies for defective structural conditions, but much yet remains to be done. There seems to be a general opinion among experts that progress now lies in the direction of raising the general standard of hygiene, by means of cleanliness, ventilation, and light, the maintenance of proper space between machines and between the workers employed, freedom from dust, and control of temperature, all of which conditions are now felt to be more important on the whole than the adoption of specific precautions for dangerous trades.

(3) In regard to wages, no discussion can here be attempted of the proposed law re wages boards, which would demand an article to itself, though I may perhaps be allowed to say in passing 
that I regard the extreme poverty and underpayment of large classes of workers as the main evil of their condition, and fully believe that Factory Acts and Public Health Acts, valuable as these are, cannot adequately protect workers who are too underpaid to combine together for the enforcement of the law. But the present law as to payment of wages undoubtedly needs strengthening. The Women's Trade Union League has for many years demanded the abolition of fines and deductions. Miss Clementina Black, in her book, Sweated Industry (p. 41 et seq.), tells us how fines, which the outsider might innocently suppose to be instituted as a means of preserving discipline amongst giddy young workers, are actually a profit-making device among low-class employers. Miss Black quotes wage-books in which fines and deductions amounted to a sum varying from 10 to 30 per cent. of wages. In another case workers were charged rent for their place in the factory. In others charges are made for use of machines, or even for cleaning the workroom, one ingenious employer paying $15 s$. to the scrubber, while the pence collected from the workers amounted to twice that sum. Some charge for hot water to make tea, and it can be easily seen that even a small charge of this kind, when put upon a number of workers, would bring in a sum much in excess of the cost of water. Deductions for spoilt work are often grossly unfair, as with jam and preserve making, where one or two jars in a few hundreds are sure to crack with the heat. The unlucky girl who chances to wash the cracked jar will be charged for damage she is probably entirely unconnected with, and may even be made to pay the selling price of the pot of jam. Other deductions are inflicted for punishment; and of these Miss Black tells a significant story. One of the best employers who have come within her observation said, when questioned on this head, "If I could not run a factory without fines I should be ashamed to run one at all." Another employer of a very different stamp defended himself against a charge of excessive fining by asserting that, without fines, his factory would be a "bear-garden." Comment is superfluous. Perhaps the worst kind of fine is that used by employers who deduct a surplus from those piece-workers who make up a total rather better than usual. I have myself been told by $\mathrm{a}_{\mathrm{u}}$ girl in reference to a certain factory: "It doesn't do to work too well there-they cut you down directly." Miss Black mentions a factory where the foreman deducts 1 or 2 shillings from the week's payment if he thinks the girl entitled to it has " earned too much." Can anything more demoralising than such a system be imagined? Fines

No. 70.-VoL. XVIII. 
and deductions should be abolished, and the "Particulars Clause," which provides that the worker shall be made fully acquainted with the piece rates he or she is working for, needs extension to all piece-work trades. In isolated cases employers in industries not under the clause have voluntarily adopted it, showing that they realise the advantage of having a fair and above-board agreement. Legislation is also necessary to bring out-workers more completely under the Truck Acts, the decision of the High Court in Squire v. The Midland Lace Co. having unfortunately placed outside the protection of the law a large class of needy workers. ${ }^{1}$

\section{B. L. HuTchINS}

1 See report on the Truck Acts in the Factory Inspector's Report for 1906, p. 239, and a report of the above case in the Factory Inspector's Report for 1904, p. 281 The Court stated that it gave its decision reluctantly and recommended amendment of the law. 